\title{
Derajat Kerusakan Mukosa Esofagus pada Anak dengan Penyakit Refluks Gastroesofagus
}

\author{
Berlian Hasibuan, * Badriul Hegar, ** Muzal Kadim ** \\ *Departemen Ilmu Kesehatan Anak, Rumah Sakit DR. Pirngadi, Medan \\ ** Departemen Ilmu Kesehatan Anak Fakultas Kedokteran Universitas Indonesia Rumah Sakit Dr. Cipto \\ Mangunkusumo, Jakarta
}

Latar belakang. Refluks gastroesofagus (RGE) yang berlangsung lama, baik durasi maupun frekuensi dapat menyebabkan berbagai derajat kerusakan mukosa esofagus atau esofagitis. Esofagitis atau penyakit refluks gastroesofagus (PRGE) yang tidak segera ditangani dapat mempengaruhi kualitas hidup anak. Oleh karena itu pembuktian kerusakan mukosa esofagus pada setiap anak yang secara klinis dicurigai mengalami esofagitis menjadi amat penting.

Tujuan. Menilai derajat kerusakan mukosa esofagus atau esofagitis pada anak yang secara klinis memperlihatkan gejala PRGE.

Metode. Penelitian deskriptif yang dilakukan secara retrospektif terhadap data hasil pemeriksaan endoskopi dari pasien dengan gejala klinis PRGE, dilakukan pada 1 Januari sampai 31 Desember 2009, di Divisi Gastrohepatologi Departemen Ilmu Kesehatan Anak FKUI/RSCM. Derajat kerusakan mukosa esofagus ditentukan berdasarkan kriteria Los Angeles.

Hasil. Di antara 58 pasien dengan gejala klinis PRGE yang dilakukan endoskopi, didapatkan 51 pasien $(87,9 \%)$ mengalami kerusakan mukosa esofagus (esofagitis), yang mencakup $21,6 \%$ esofagitis derajat A, 33,3\% esofagitis derajat $\mathrm{B}, 25,5 \%$ esofagitis derajat $\mathrm{C}$, dan $19,8 \%$ esofagitis derajat $\mathrm{D}$. Tujuh pasien $(12,1 \%)$ tidak ditemukan kerusakan mukosa esofagus. Gejala klinis terbanyak adalah mual dan muntah pada 25 pasien $(43,1 \%)$, diikuti nyeri perut berulang daerah ulu hati dan regurgitasi, masing-masing pada 20 pasien $(34,5 \%)$.

Kesimpulan. Kerusakan mukosa esofagus akibat refluks gastroesofagus pada anak merupakan keadaan yang perlu diwaspadai pada setiap anak dengan gejala klinis regurgitasi dengan volume dan frekuensi berlebihan, serta gejala klinis PRGE. Sari Pediatri 2012;14(1):19-23.

Kata Kunci: anak, regurgitasi, refluks gastroesofagus, penyakit refluks gastroesofagus

\footnotetext{
Alamat korespondensi:

Dr. Berlian Hasibuan, Sp.A. Departemen Ilmu Kesehatan Anak Fakultas Kedokteran Universitas Sumatera Utara/ RSUP H.Adam Malik Jl. Bunga Lau no.17 Medan. Telp. (061) 8361721 - 8365663, Fax. (061) 8361721 E-mail: bikafkusu@telkom.net; kotak Pos 697 Medan - 20136.
}

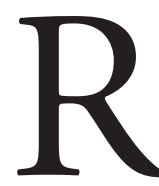
efluks gastroesofagus adalah pasase isi lambung ke dalam esofagus yang berlangsung secara involunter. ${ }^{1}$ Refluks esofagus merupakan fenomena yang sering dijumpai pada bayi dengan gejala klinis bervariasi, mulai dari gejala yang ringan berupa gumoh yang terjadi setelah 
makan/minum (regurgitasi) sampai menolak minum dan gagal tumbuh (penyakit refluks gastroeosfagus). ${ }^{2}$ Penyakit refluks gastroesofagus dihubungkan dengan paparan isi lambung/asam lambung dengan frekuensi dan intensitas yang berlebihan. ${ }^{3}$

Isi lambung yang masuk ke dalam esofagus tidak hanya makanan/minuman yang baru saja dikonsumsi, tetapi dapat pula disertai asam, pepsin, atau empedu yang bersifat korosif sehingga dapat merusak mukosa esofagus (esofagitis). Kerusakan mukosa esofagus diperlihatkan secara klinis oleh anak dengan keluhan nyeri perut terutama ulu hati, mual, muntah, dan menolak makan karena sakit menelan. Pada anak yang lebih besar mengeluh nyeri di daerah dada. ${ }^{4}$ Paparan asam lambung yang berlangsung kronis dapat menyebabkan perubahan epitel esofagus dari stratified squamous menjadi epitel simple collumnar (Barret's esophagus). Esofagitis yang berat dapat menyebabkan komplikasi perdarahan dan struktur esofagus. ${ }^{4-6}$

Pemeriksaan endoskopi saluran cerna atas merupakan alat diagnostik pilihan untuk membuktikan adanya esofagitis yang dilanjutkan dengan pemeriksaan biopsi jaringan mukosa. ${ }^{7,8}$ Kriteria Los Angeles digunakan oleh pusat pendidikan dan pelayanan kesehatan anak di berbagai negara untuk mendiagnosis esofagitis berdasarkan pemeriksaan endoskopi. ${ }^{6}$ Sebagai langkah awal, kami ingin melaporkan kejadian esofagitis berdasarkan pemeriksaan endoskopi menurut kriteria Los Angeles untuk memberikan gambaran awal mengenai derajat kerusakan mukosa esofagus pada anak yang secara klinis diduga mengalami esofagitis/ penyakit RGE

Tujuan penelitian untuk menilai derajat kerusakan mukosa esofagus sebagai komplikasi refluks gastroesofagus melalui pemeriksaan endoskopi saluran cerna atas, yang dihubungkan gejala klinis dan usia.

\section{Metode}

Penelitian deskriptif dilakukan secara retrospektif terhadap data hasil pemeriksaan endoskopi dari pasien dengan gejala PRGE, dalam rentang waktu 1 Januari sampai 31 Desember 2009, di Divisi Gastrohepatologi Departemen Ilmu Kesehatan Anak, FKUI/- RSCM. Usia pasien antara 9 bulan sampai 12,5 tahun (median $43 \mathrm{bln}$ ). Tingkat kerusakan mukosa esofagus dinilai berdasarkan kriteria Los Angeles.

\section{Hasil}

Lima puluh delapan pasien ikut dalam penelitian, terdiri dari 32 anak laki-laki dan 26 anak perempuan. Delapan belas pasien $(20,7 \%)$ berusia $0-24$ bulan, 14 pasien $(24,13 \%)$ berusia $>24-60$ bulan, dan 26 pasien $(44,82 \%)$ berusia di atas 60 bulan (median 43 bln). Mual/muntah, nyeri perut berulang/ulu hati, dan regurgitasi merupakan gejala klinis terbanyak yang diperlihatkan oleh pasien, yaitu masing-masing $43,1 \%$, $34,5 \%$, dan 34,5\% (Tabel 2).

Berdasarkan kriteria Los Angeles, 51 pasien mengalami kerusakan mukosa esofagus. Esofagitis derajat A pada 11 pasien $(21,6 \%)$, esofagitis derajat B pada 17 pasien

Tabel 1. Klasifikasi kerusakan mukosa esofagus berdasarkan kriteria Los Angeles ${ }^{6}$

\begin{tabular}{ll}
\hline Derajat esofagitis & Keterangan \\
\hline Derajat A & $\begin{array}{l}\text { Perubahan mukosa minimal, beru- } \\
\text { pa kerusakan mukosa dengan luas } \\
\end{array}$ \\
& $<5 \mathrm{~mm}$. \\
Derajat B & $\begin{array}{l}\text { Perubahan/kerusakan mukosa } \\
\text { minimal satu buah dengan luas }>\end{array}$ \\
& $5 \mathrm{~mm}$, tetapi tidak berhubungan \\
& antara puncak lipatan yang satu \\
& dengan yang lainnya. \\
& Terdapat hubungan antara satu \\
& puncak kerusakan mukosa dengan \\
kerajat C & melingkan mukosa lain, tetapi tidak \\
& Lesi sirkumferensial pada mukosa \\
\hline
\end{tabular}

Tabel 2. Karakteristik subyek penelitian

\begin{tabular}{lc}
\hline Karakteristik & Jumlah \\
\hline Jenis kelamin & \\
Laki-laki & 32 \\
Perempuan & 26 \\
Usia (bulan) & \\
$0-24$ & 18 \\
$>24-60$ & 14 \\
$>60$ & 26 \\
Keluhan & \\
Mual muntah & 25 \\
Nyeri perut berulang daerah uluhati & 20 \\
Gumoh/regurgitasi & 20 \\
Menolak makan/minum & 18 \\
Berat badan sulit naik & 12 \\
Hematemesis melena & 12 \\
Back arching & 1 \\
\hline
\end{tabular}


(33,3\%), esofagitis derajat C pada 13 pasien $(25,5 \%)$, dan dan esofagitis derajat D pada 10 kasus $(19,8 \%)$. Tujuh pasien lainnya (12,1\%) tidak ditemukan kerusakan mukosa esofagus. Hubungan kerusakan mukosa esofagus dan gejala klinis yang diperlihatkan dan usia anak tertera pada Tabel 3 dan 4.

Nilai p secara keseluruhan 0,344, menunjukkan tidak ada hubungan yang bermakna antara gejala klinis dan derajat esofagitis.

Dari hasil temuan kami di ketahui nilai p secara keseluruhan bernilai 0,322. Hal tersebut menunjukkan bahwa tidak ada hubungan yang bermakna antara golongan umur dan derajat esofagitis.
Penyakit RGE terjadi bila terdapat ketidakseimbangan antara faktor yang mencegah RGE (defence mechanisms) dan yang menyebabkan RGE (aggressive factors). Isi dari cairan lambung yang masuk ke dalam lumen esofagus dapat berupa air liur, makananminuman, cairan sekresi lambung, pankreas, atau empedu. Peningkatan frekuensi dan durasi episod refluks, serta bertambahnya zat toksik yang masuk ke dalam esofagus merupakan hal yang berperan pada patofisiologi penyakit RGE. ${ }^{1}$

Sfingter esofagus bagian bawah (SEB) merupakan barier anti-refluks terpenting. Pada keadaan normal, SEB akan mengalami relaksasi sebagai respons

Tabel 3. Derajat kerusakan mukosa esofagus dan gejala klinis pasien

\begin{tabular}{|c|c|c|c|c|c|c|c|}
\hline \multirow[b]{2}{*}{ Gejala klinis } & \multicolumn{3}{|c|}{ Derajat kerusakan mukosa esofagus } & \multicolumn{2}{|c|}{ (Kriteria Los Angeles) } & \multirow[b]{2}{*}{$\mathrm{n}$} & \multirow[b]{2}{*}{$\mathrm{p}$} \\
\hline & $\begin{array}{c}\text { Tanpa } \\
\text { esofagitis }\end{array}$ & $\begin{array}{c}\text { Esofagitis } \\
\text { derajat A }\end{array}$ & $\begin{array}{l}\text { Esofagitis } \\
\text { derajat B }\end{array}$ & $\begin{array}{l}\text { Esofagitis } \\
\text { derajat C }\end{array}$ & $\begin{array}{l}\text { Esofagitis } \\
\text { derajat D }\end{array}$ & & \\
\hline Gumoh/regurgitasi & 6 & 2 & 5 & 4 & 3 & 20 & 0,083 \\
\hline Mual muntah & 3 & 3 & 7 & 7 & 5 & 25 & 0,083 \\
\hline Nyeri perut/ulu hati & 0 & 4 & 6 & 6 & 4 & 20 & 0,05 \\
\hline Menolak makan & 0 & 3 & 6 & 3 & 6 & 18 & 0,008 \\
\hline Berat badan tak naik & 0 & 3 & 3 & 2 & 4 & 12 & 0,002 \\
\hline Hematemesis/melena & 0 & 3 & 3 & 2 & 4 & 12 & 0,002 \\
\hline Back arching & 0 & 1 & 0 & 0 & 0 & 1 & 0,0001 \\
\hline
\end{tabular}

Tabel 4. Derajat kerusakan mukosa esofagus dan kelompok usia pasien

\begin{tabular}{|c|c|c|c|c|c|c|c|}
\hline \multirow[b]{2}{*}{$\begin{array}{l}\text { Kelompok usia } \\
\text { (bulan) }\end{array}$} & \multicolumn{5}{|c|}{ Derajat kerusakan mukosa esofagus (Kriteria Los Angeles) } & \multirow[b]{2}{*}{$\mathrm{n}$} & \multirow[b]{2}{*}{$\mathrm{p}$} \\
\hline & $\begin{array}{l}\text { Tanpa esofa- } \\
\text { gitis }\end{array}$ & $\begin{array}{c}\text { Esofagitis } \\
\text { derajat A }\end{array}$ & $\begin{array}{l}\text { Esofagitis } \\
\text { derajat B }\end{array}$ & $\begin{array}{l}\text { Esofagitis } \\
\text { derajat C }\end{array}$ & $\begin{array}{l}\text { Esofagitis } \\
\text { derajat D }\end{array}$ & & \\
\hline $0-24$ bulan & 4 & 3 & 7 & 2 & 2 & 18 & 0,212 \\
\hline$>24-60$ bulan & 2 & 1 & 4 & 3 & 4 & 14 & 0,223 \\
\hline$>60$ bulan & 1 & 7 & 6 & 8 & 4 & 26 & 0,105 \\
\hline Jumlah & 7 & 11 & 17 & 13 & 10 & 58 & \\
\hline
\end{tabular}

\section{Pembahasan}

Refluks gastroesofagus Terjadi apabila pasase isi lambung ke dalam esofagus berlangsung secara involunter dan merupakan keadaan yang sering ditemukan pada bayi. ${ }^{1}$ Refluks gastroesofagus dapat berupa RGE fisiologis (normal) atau RGE patologis yang dikenal sebagai penyakit RGE, yaitu apabila refluks gastroesofagus dikatakan patologis apabila terjadi komplikasi. Esofagitis merupakan komplikasi yang sering ditimbulkan akibat paparan asam lambung pada dinding esofagus secara berlebihan. ${ }^{9}$ terhadap proses menelan sehingga minuman atau makanan akan masuk ke dalam lambung. ${ }^{1}$ Relaksasi sementara SEB (transient LES relaxation $=$ TLSR), yaitu relaksasi sfingter esofagus yang tidak berhubungan dengan proses menelan merupakan mekanisme utama yang menyebabkan isi lambung kembali ke dalam esofagus.

Klirens esofagus merupakan rangkaian proses, (1) pengeluaran asam di dalam esofagus oleh gerakan peristaltik esofagus sehingga sisa asam yang tertinggal sangat sedikit; (2) netralisasi sisa asam yang tertinggal oleh air liur yang tertelan. Semakin lama 
durasi episod refluks berlangsung semakin terganggu mekanisme klirens esofagus. Selain itu, daya gravitasi juga memegang peran dalam mekanisme klirens esofagus. ${ }^{1}$ Isi refluks yang bersifat korosif dan ketahanan mukosa esofagus merupakan faktor lain yang dapat mempengaruhi ketahanan mukosa esofagus.

Regurgitasi merupakan gejala klinis yang paling sering dijumpai pada bayi. Keadaan tersebut merupakan gejala awal RGE dan sering digunakan sebagai petanda RGE pada bayi. Sekitar 70\% bayi kemungkinan mengalami RGE datang dengan keluhan regurgitasi. Sekitar 25\% bayi dengan regurgitasi dikeluhkan oleh orangtua sebagai suatu hal yang bermasalah, baik frekuensi maupun volume refluks. ${ }^{10,11}$

Jumlah anak laki-laki dan perempuan dengan gejala klinis PRGE kurang lebih sama. Peran genetik terhadap kejadian RGE, mulai dikaji para ahli sejak banyak laporan yang memperlihatkan gejala RGE dalam satu keluarga. ${ }^{12}$ Prevalens RGE dilaporkan lebih besar pada bayi kembar monozigot dibanding bayi kembar dizigot. ${ }^{13}$ Kelainan pada kromosom $13 \mathrm{q}$, antara mikrosatelit D13S171 dan D13S263 ditemukan pada anak dengan PRGE pada lima keluarga dari beberapa generasi. ${ }^{14}$ Akan tetapi, kelainan yang sama tidak ditemukan pada lima keluarga lain. Hal tersebut mungkin disebabkan karena heterogenisitas genetik dari RGE dan gejala klinis yang berbeda di antara pasien yang diteliti. ${ }^{15}$

Gejala klinis nyeri, pada umumnya timbul akibat paparan asam berlebihan atau telah berlangsung lama. Bayi akan menjadi rewel, cengeng, dan kadangkadang menjerit. Bayi juga sering memperlihatkan posisi hiperekstensi pada tulang belakang pada saat atau setelah makan (back arching). ${ }^{1}$ Pada esofagitis berat dijumpai darah pada isi muntahan, nyeri atau gangguan menelan, dan darah pada tinjanya. ${ }^{3}$ Refluks gastroesofagus patologik yang berlangsung terus menerus dapat menyebabkan gangguan pertumbuhan. Gagal tumbuh terjadi apabila jumlah masukan kalori lebih sedikit dibanding jumlah yang keluar. Makin lama regurgitasi berlangsung, makin banyak orangtua menyatakan bahwa RGE merupakan masalah. ${ }^{3}$

Penelitian di India didapatkan $30 \%$ bayi dan $85 \%$ anak usia $12-24$ bulan dengan regurgitasi memperlihatkan gejala klinis yang diduga suatu PRGE. ${ }^{16}$ Penelitian di Children Hospital Houston, Texas dijumpai nyeri dada 55\%, nyeri epigastrium dan perut $75 \%$, regurgitasi $45 \%$, mual dan muntah 50\%, sedangkan nyeri menelan 15\%-20\% (disfagia).
Penurunan berat badan 15\%. Tidak terdapat perbedaan bermakna dari gender. ${ }^{17}$ Vandenplas ${ }^{7}$ melaporkan esofagitis tanpa keluhan (asymptomatic eosophagitis), bahkan terdapat kasus yang sudah menjadi striktur tanpa disertai keluhan esofagitis.

Kami menemukan mual/muntah, nyeri perut, dan menolak makan/minum juga merupakan gejala klinis yang paling sering dikeluhkan oleh pasien dengan PRGE. Walaupun demikian, gejala klinis yang diperlihatkan oleh pasein tidak dapat memprediksi tingkat kerusakan mukosa esofagus (Tabel 3). Hal tersebut dapat diketahui dari hasil perhitungan statistik, nilai p untuk mual muntah 0,147 , nyeri perut 0,05 , menolak makan/minum 0,008, keseluruhan 0,344. Sehingga disimpulkan tidak ada hubungan antara gejala klinis dan derajat kerusakan mukosa esofagus.

Refluks gastroesofagus yang berlangsung lama atau terlalu sering berulang dapat menyebabkan kerusakan mukosa esofagus (esofagitis) yang dapat dibuktikan dengan pemeriksaan endoskopi. Walaupun tidak ada kerusakan mukosa esofagus bukan berarti tidak ada PRGE, karena sering kali memperlihatkan kelainan pada pemeriksaan histopatologi jaringan biopsi, yang dikenal sebagai non-erosive reflux disease (NERD). ${ }^{18}$

Kriteria Los Angeles merupakan salah satu cara untuk menentukan derajat atau tingkat kerusakan mukosa esofagus (esofagitis) yang banyak digunakan oleh pusat pelayanan kesehatan anak di dunia, termasuk di Departemen Ilmu Kesehatan Anak RSCM. Kami mendapatkan $51 / 58$ pasien $(87,9 \%)$ mengalami kerusakan mukosa esofagus; $14 / 18(77,8 \%)$ berusia 0-24 bulan, 12/14 (85,7\%) berusia >24-60 bulan, dan 25/26 (96,1\%) berusia $>60$ bulan. Data tersebut memperlihatkan bahwa semakin bertambah usia, semakin besar prevalens kerusakan mukosa esophagus. Mulyani $\mathrm{dkk}^{19}$ menemukan $90 \%$ anak berusia 12-60 bulan dengan kesulitan makan mengalami esofagitis. Namun dari penelitian kami, tidak ada hubungan antara kelompok umur dan derajat kerusakan mukosa esofagus.

Bila dilihat dari derajat kerusakan mukosa esofagus yang terjadi, maka derajat $\mathrm{C}$ dan $\mathrm{D}$ ditemukan pada 4/14 anak usia 9-24 bulan (28,6\%), 7/12 anak usia $>24-60$ bulan (58,3\%), dan 12/25 anak usia > 60 bulan (48\%). Data tersebut memperlihatkan bahwa kerusakan mukosa esofagus yang lebih berat ditemukan pada anak usia di atas 24 bulan. Temuan tersebut menjadi dasar pertimbangan bagi setiap dokter untuk tidak menganggap refluks gastroesofagus hanya sebagai 
gumoh biasa tetapi sebagai suatu keadaan yang perlu mendapat perhatian. Hal tersebut penting agar refluks gastroesofagus tidak menimbulkan komplikasi yang dapat mengganggu kualitas hidup anak di kemudian hari.

Sebagai kesimpulan, kerusakan mukosa esofagus akibat refluks gastroesofagus pada anak merupakan keadaan yang perlu diwaspadai pada setiap anak dengan gejala klinis regurgitasi dengan volume dan frekuensi berlebihan, serta gejala klinis PRGE.

\section{Daftar pustaka}

1. Vandenplas Yvan, Hegar Badriul. Diagnosis and treatment of gastroesophageal reflux disease in infants and children. J Gastroenterol Hepatol 2000;15:593603.

2. Orenstein S, Peters J, Khan S, Youssef N, Hussein SZ. Gastroesophageal reflux disease. Dalam : Kliegman RM, Behrman RE, Jenson HB, Stanton BF, penyunting. Nelson Textbook of Pediatrics, Edisi ke-18. Philadelphia: Elsevier Saunders; 2007. h. 1547-58.

3. Hegar B, Vandenplas Y. Review : Gastro-oesophageal refluks in Infancy. J Gastroenterol Hepatol 1999;14 : 13-9.

4. Vandenplas Y, Hegar B. Esophagitis in children. Dalam: Trikono P, Hegar B, dkk. Hot Topics in Pediatrics II. Jakarta: Balai Penerbit FKUI; 2002. h. 74-83.

5. Vandenplas Y, Devreker T, Hauser B. Gastroesophageal reflux and chronic respiratory disease: past, present, and future. J de Pediatrica. 2007;83:196-200.

6. Lundell LR, Dent J, Bennet JR. Endoscopy assessment of esophagitis : clinical and functional correlation and further validation of the Los Angeles Classification. Gut. 1999;45:172-80.

7. Vandenplas Y. Gastroesophageal reflux. Dalam: Wyllie R, Hyams JS, Kay M, penyunting. Pediatric Gastrointestinal Liver Disease. Edisi ke-3. Philadelphia: Elsevier Saunders; 2006. h. 305-21.

8. Gold BD. Gastroesophageal reflux disease. Dalam : Bishop WP, penyunting. Pediatric practice gastroenterology. Edisi ke-3. New York: Mc Graw Hill, 2010. h. 168-
70 .

9. Vandenplas Y, Hegar B, Verghote M, Hauser B, Kaufman L. Eur J Pediatr 2004;163:300-4.

10. Hegar B, Boediarso A, Firmansyah A, Vandenplas Y. Investigation of regurgitation and other symptoms of gastro-esophageal reflux in Indonesian infants. World J Gastroenterol 2004;10:1795-7.

11. Ashorn M, Ruuska T, Karikoski R, Laippala P. The natural course of Gastroesophageal reflux disease in children. Scand J Gastroenterol 2002;37:638-41.

12. Trudgill NJ, Kapur KC, Riley SA. Familial clustering of reflux symptoms. Am J Gastroenterol 1999;94:1172-8.

13. Cameron AJ, Lagergren J, Henriksson C. Gastroesophageal reflux disease in monozygotic and dizygotic twins. Gastroenterology 2002;122:55-9.

14. Hu FZ, Preston RA, Post JC, White GJ, Kikuchi LW, Wang $\mathrm{X}$, dkk. Mapping of a gene for severe pediatric gastroesophageal reflux to chromosome 13q14. JAMA 2000;284:325-34.

15. Orenstein SR, Shalaby TM, Barmada MM, Whitcomb DC. Genetics of gastroesophageal reflux disease: a review. J Pediatr Gastroenterol Nutr 2002;34:506-10.

16. De S, Rajeshwari K, Kalra KK, Gondal R, Malhotra V, Mittal SK. Gastroesophageal reflux in infants and children in north India. Trop Gastroenterol 2001;22:99102.

17. Huda M. Multidimensional measure for gastroesophageal reflux disease (MM-GERD) symptom in children: a population based study: Acta Pediatrica 2008;12:9297.

18. Mahmud TS., Sunny ZH, Theresia M. S. Morphometric histology for Infant gastroesophageal reflux disease: Evaluation of reliability in 497 Esophageal Biosies. J Pediatr Gastroenterol Nutr 2007;44:27-34.

19. Mulyani L, Hegar B, Tumbelaka AR, Krisnuhoni E. Reflux esophagitis in children with feeding problems: a preliminary study. Paediatr Indones 2010;50:284-90.

20. Mason Robert D, Lind Douglas A. Teknik statistika untuk bisnis \& ekonomi. Jakarta: Penerbit Erlangga; 1996. h. 101.

21. Priyatno D. Mandiri belajar SPSS (statistical product and service solution) untuk analisis data dan uji statistik. Mediakom; 2009. h. 109-14. 